\title{
The Political Role of the Ethnic Factor around Elections in the Democratic Republic of the Congo
}

\author{
Hubert Kabungulu Ngoy-Kangoy
}

\begin{abstract}
This paper analyses the role of the ethnic factor in political choices in the Democratic Republic of the Congo, and its impact on democratisation and the implementation of the practice of good governance. This is done by focusing especially on the presidential and legislative elections of 1960 and 2006.
\end{abstract}

The Congolese electorate is known for its ambiguous and paradoxical behaviour. At all times, ethnicity seems to play a determining role in the

* Hubert Kabungulu Ngoy-Kangoy is a research fellow at the Centre for Management of Peace, Defence and Security at the University of Kinshasa, where he is a Ph.D. candidate in Conflict Resolution. The key areas of his research are good governance, human security and conflict prevention and resolution in the SADC and Great Lakes regions. He has written a number of articles and publications, including La transition démocratique au Zaïre (1995), L'insécurité à Kinshasa (2004), a joint work, The Many Faces of Human Security (2005), Parties and Political Transition in the Democratic Republic of Congo (2006), originally in French. He has been a researcher-consultant at the United Nations Information Centre in Kinshasa, the Centre for Defence Studies at the University of Zimbabwe, the Institute of Security Studies, Pretoria, the Electoral Institute of Southern Africa, the Southern African Institute of International Affairs and the Human Sciences Research Council, Pretoria.

The article was translated from French by Dr Marcellin Vidjennagni Zounmenou. 
choice of leaders and so the politicians, entrusted with leadership, keep on exploiting the same ethnicity for money. Although the East-West rift is a reality which was particularly eminent during the elections of 2006, it is something that should be relativised. This divide is however not always linked to the ethnic factor. The analysis is more complex. At the legislative level, the voting pattern has always shown a contrast, particularly with the individual vote, the modification of ethnic allegiance, and the conflict of ethnic fidelity, as well as ethnic clientelism in its various forms. Individual interest often confronts and/or merges with the interest of the group, leading to a rather casual relationship.

Finally, political identification can be expressed in political, linguistic, economic or regional ways. The very subjective character of the vote has a negative impact on the political choices, and consequently on good governance, which then shows up, as often is the case, as incompetence and corruption. The study ends with some recommendations that may eventually contribute to voting for the sake of the advantages of democracy and the exigencies of good governance.

\section{Introduction}

In the Democratic Republic of the Congo (DRC) the period around elections has always been a moment of rift between the present and the past, a moment in which the question of identity is expressed in different ways.

Using both the psychoanalytic and the psychological approaches in the construction of identity, Eric H. Erikson (1902-1994) refers to identity as a process which is developed throughout existence, especially in times of rift. In this regard, 'identity is no longer regarded as a substance or an indispensable attribute in individuals or groups, as the case was with culture, for example. ${ }^{1}$ Dominant contemporary theory

1 To refresh our memories, 'in 1952 Alfred Kroeber and Clyde Kluckhohn published a compilation of various efforts to define the notion of culture - or notions close to it - in the social sciences. They found no less than 164 . Their version did not stop only at their planned definition (content, function, properties) but went further to 
insists that the image of self-esteem and communal or political identities are developed in the contradictions between individuals, groups and their ideologies. They all stress that the starting point of identification is psychological and that it never stops to build and update itself' (Ruano-Borbalan 1998:29).

The aim of this study is to analyse the ethnic factor as a basis for political choices in the DRC, the impact of the ethnic factor on democratisation, and the implementation of good governance. In fact, for Young (1979:107), 'no serious study on the political evolution of the Congo can neglect the difficult problem of "tribalism" or what may be referred to as "ethnicity". This is one of the major issues that place a question mark over the very existence of the Congolese entity'.

The role of the ethnic component will be analysed only at the level of the presidential and legislative elections of 1960 and 2006. It should be noted that the 1965 presidential elections could not be organised due to differences between Tshombe and Kasa Vubu in the race for power.

\section{Context}

\section{The electoral experience of 1960}

The first elections took place in May 1960. The entire Congolese electoral assembly was called upon to choose parliamentarians and political councillors for the chamber of representatives and the provincial assemblies. In total, 250 lists (individual and collective) were presented to voters with a view to electing 137 parliamentarians. In a population of

the usage of the word in the widest sense'. See Journet 2002:1. But 'studies on contact and cultural change (constructivism - cultures on the move) caused in the seventies a revision of the notion of culture. According to Fredrik Barth (1969), culture is revealed more and more as an element of strategy, often unconsciously, by social stakeholders, especially if they are involved in social or political battles. Consequently the notion of identity seems to explain that of culture... The notion of culture is that of everyday usage, but its definition always seems to escape us. Its development, in all cases, is closely linked to that of human science' (Journet 2002:11). 
over 15 million inhabitants (Congo 1960), only 2733595 voters participated in the elections (Congo 1960:264).

The Mouvement National Congolais of Lumumba (MNC-L) (41 seats) and its allies won a total of 64 seats out of 137 in the chamber (Congo 1960:269). Katanga province did not elect a single pro-Lumumba parliamentarian. The rift between the 'people from the upper side' (Ba-Likolo) and the 'people from the lower side' (Bato ya se) was already a reality at the time, and Leopoldville managed to elect only one MNC representative in the district of Lake Leopold (Mai-Ndombe). This is confirmed by Benoit Verhaegen: The capital 'Leopoldville had three major ethnic groups: the Bakongo, who were slightly in the majority, the people of the "upper side", who belonged to ethnic groups foreign to Leopoldville and non-Bakongo, and finally the Bateke-Bahumbu, the first occupants and holders of land certificates over most of the Leopoldville area' (Congo 1965:208). ${ }^{2}$ This configuration seems to have evolved with time into a more broad-based structure.

The electoral success obtained by Lumumba was very limited. Out of 34 purely MNC-L seats, 21 came from the Eastern Province of which the capital Kisangani had always been his headquarters. Using his pantribal base doctrine in his political campaign, Lumumba mainly focused on the Mongo ethnic group, which was very fragmented and extraordinarily scattered all over the country (Kusu, Lokele, Tetela, Mongo, etc.). Lumumba himself belonged to the Tetela ethnic group. ${ }^{3}$

2 Kwilu and Lake Leopold II later became the province of Bandundu. All the groups living along the upper Congo River between the provinces of Equateur and Katanga are regarded as 'people from the upper side'. The 'people from the lower side' are those in the provinces of Bandundu and Lower Congo. While the former are patrilineal, the latter are mostly matrilineal.

3 In 1960, 'the provinces of the Congo could be divided into two categories: those where political consciousness in the cities was already well mastered but where energy was focused on other conflicts like those between 'sons of the soil' and 'foreigners', and those where politics was still reserved for only the elites. Kasaï and Katanga belong to the first category. In these two categories, the conflict that arose during local elections in 1957 and 1959 continued to dominate political life' (Weiss 1994:58). 


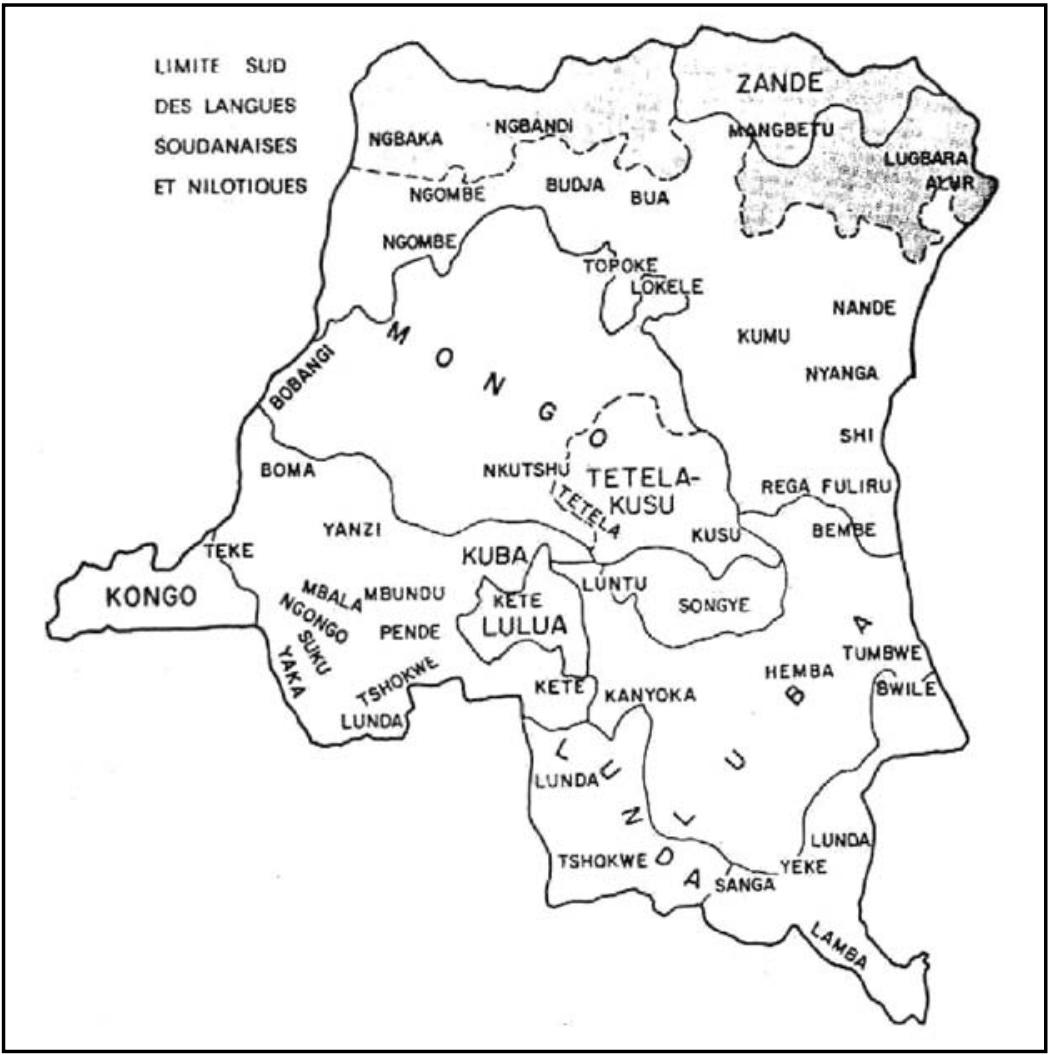

Source: Young 1968:113.

In Katanga and Kasaï, another phenomenon was developing. The Luba, who were voting for Kalonji, Lumumba's greatest adversary in Kasaï, were giving their vote of confidence to Sendwe, friend and ally of Lumumba in northern Katanga. But in Elizabethville (Lumumbashi), the same Baluba of Kasaï voted for the Katangese National Confederation (CONAKAT) and ipso facto, Tshombe. Why this contradiction? The reason is because Kalonji had issued an injunction against Belgians who supported Tshombe. At the same time, the Lulua and the Baluba who were killing each other in Kasaï in a determined fashion, were fraternising 


\section{Hubert Kabungulu Ngoy-Kangoy}

and working together in welfare and cultural unions in Katanga (Weiss 1994:59). In fact, Weiss points out that 'in Kasaï, the first urban preoccupation of the leaders were closer to the real ethno-political divisions of their provinces, be it in Leopoldville or in Katanga. In fact, political life in Luluabourg was initially centred on the fight between the Lulua 'sons of the soil' and the Baluba (from Kasaï) who were considered foreigners' (Weiss 1994:59). But 'as far as Leopoldville is concerned, the initial conflict led to the Bakongo opposing the people of the Upperside' (Congo 1960:208) - the Baswahili and the Kasaians.

Map 2: The elections of May 1960

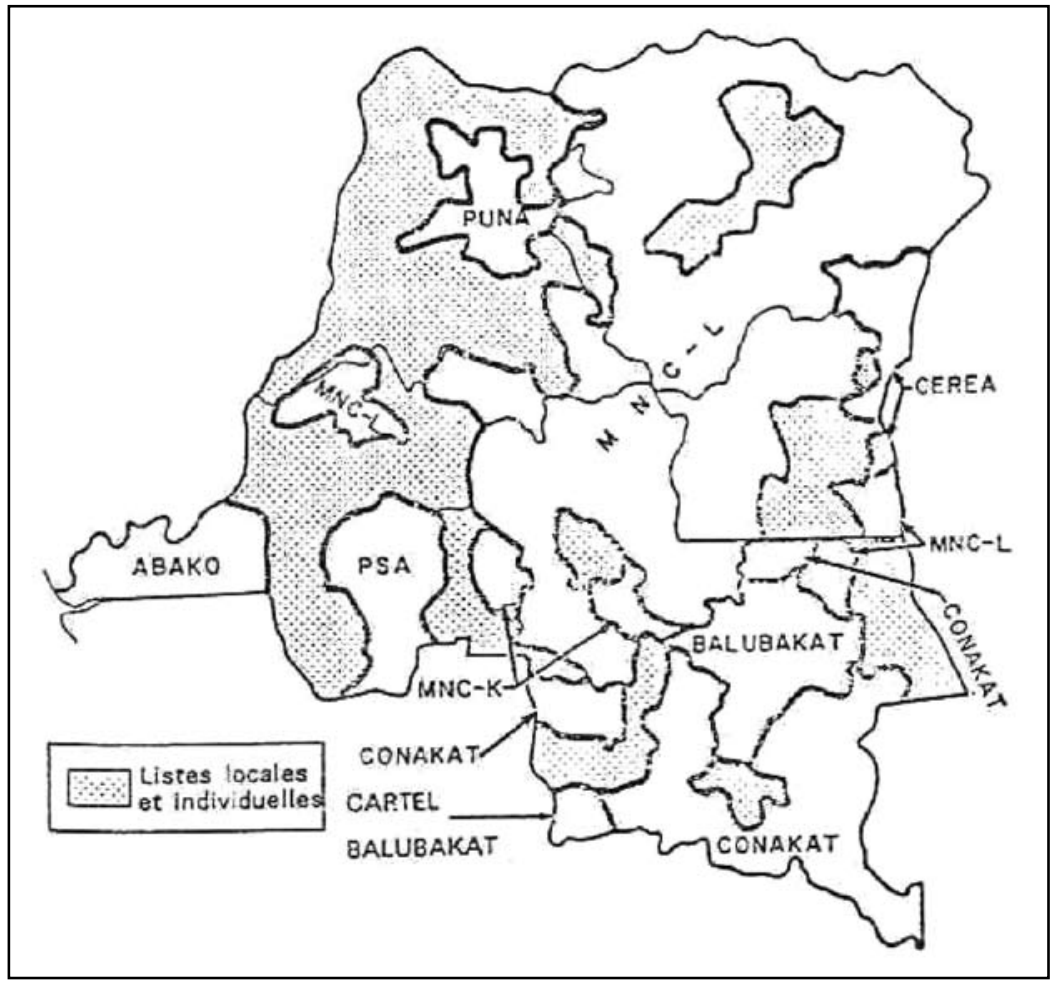

Source: Young 1968:159. Adapted from the electoral map of the Congo, prepared by J.H Pierre, Brussels, ARSOM, 1961. In this map, the PNP is not indicated separately, but is included in the category of local and individual lists. 
Katanga was integrated into the General Association of the Katanga Baluba (BALUBAKAT) which had splintered from CONAKAT since November 1959. In 1960, the conflict of power between Tshombe's CONAKAT and Sendwe's BALUBAKAT became a community rivalry between the two main ethnic groups in Katanga, the Baluba in the north (pro-Sendwe) and the Lunda in the south (pro-Tshombe).

Finally, 'the failure by the MNC-L in its effort to find a solid base in two provinces of the Congo, Leopoldville and South Katanga, had a critical influence on later events. Outside Kisangani and its Eastern Province interior and some areas in Kivu, Kasaï and Equateur, where he could count on ethnic influence, Lumumba came up against insurmountable obstacles; everywhere the situation had already polarised' (Young 1979:156).

As for the indirect election for the head of state, the election of Kasa Vubu as president of the Republic was obtained in the second round in the senate, for Lumumba eventually preferred Kasa Vubu to Bolikango (from the Equateur Province), to avoid the secession of the former province of Leopoldville (Kinshasa, Mandudu, Bas-Congo) from which Kasa Vubu originated. In fact, Lumumba, who had the majority in parliament, could get himself elected or have someone obedient to him elected. It has to be underlined that his choice was mainly based on identity. However, this identity aspect arose more from regionalism than from tribalism.

\section{The electoral experience of 2006}

In June 2006, the DRC organised for the first time in its history, a general election with universal suffrage. A total of 25420199 out of a population of about 60 million inhabitants were registered to vote. ${ }^{4}$

4 Decision no 031/CEI/BUR/06 on the announcing of provisional results of the 30 July 2006 presidential elections in the Democratic Republic of the Congo, appeared in Echos des Elections 2006:21. This announcement provoked burning tensions in the MLC camp, so that the president of the Independent Electoral Commission (IEC), Abbot Malu Malu, presented the results on national television from the IEC headquarters, without waiting to be escorted by an armed convoy. 
These elections represented the culmination of a compromise by the government of national unity on 30 June 2003, and were a result of the Global and Inclusive Accord (AGI) at Sun City, after the 1998 war.

The elections were especially characterised by three phenomena: cartelisation, independent candidates and the East-West rift. Out of 500 national parliamentarians, the People's Party for Reconstruction and Development (PPRD) of Joseph Kabila won 111 seats, followed by Jean Pierre Bemba's Movement for the Liberation of Congo with 64 seats, and Antoine Gizenga's Unified Lumumbist party (PALU) with 43 seats. The other political parties as well as the independent candidates shared the remainder of the seats. Out of 58 seats in the Kinshasa province, PALU got 6, the PPRD and Z'Ahidi's Camp de la Patrie got 4 each. ${ }^{5}$

The choice of Gizenga (34 parliamentarians) as prime minister in 2006 can only be attributed to an attempt to maintain identity equilibrium. It would have been logical to offer this post to Mbusa Nyhamuwisi's Rassemblement des Congolais Démocrates et Nationalistes (RCDN) whose coalition with Olivier Kamitatu's Alliance pour le Renouveau du Congo (ARC) brought together more than 40 parliamentarians, or even to Pierre Lumbi of le Mouvement Social pour le Renouveau (MSR) with 27 parliamentarians, not even counting his allies. Obviously, Gizenga's aura in Kwilu, his stronghold and place of origin, cannot be questioned. The election of the two PALU parliamentarians in the Eastern Kasaï falls into the same paradigm. This province is the natural extension of the Pende from Kwilu. 'A major section of the ex-Leopoldville province was part of the Kongo culture. Within the province of Badundu, the large tribes of the Hungana and Songo in Kwilu-Kwango come from the Kongo cultures. ${ }^{6}$ In the same light, the weight of Nzanga Mobutu (8 parliamentarians) in the presidential camp can only be justified by the quest for equilibrium in the corridors of state power.

5 Echos des Elections 2006:20-22 and decision no 032/CEI/BUR/06 of 7 September on the announcing of provisional results of the 30 July 2006 national parliamentary elections in the Democratic Republic of the Congo, Echos des Elections 2006:23-42.

6 Interview of the author with Professor Mbela Hiza, Kinshasa, 20 September 2007. 
The Congolese voted for 'individuals' and not programmes. Most parties did not have an ideology. The proportional list which was used in a single vote system sometimes favoured the victory of independent candidates and small parties. The Rassemblement Congolais pour la Démocratie (RCD) and its leader Azarias Ruberwa, considered as Kagame allies in the aggression against the DRC in 1998, suffered a defeat in the presidential and legislative elections, and won only 15 seats in the national assembly. The Union pour la Démocratie et le Progrès Social (UDPS) opted not to participate in the elections, feeling that Kabila had already won in advance. Yet many Kasaians had registered despite the UDPS's advice to boycott. The ambivalent Kasaian attitude caused Albert Kalonji to remind people about the experience of the 60s: 'The Kasaians should avoid the errors of the past... Kasaians have always chosen the boycott option', ${ }^{7}$ and the result has been that they have often regarded themselves as marginalised.

The presidential election led to several political cartels like the Alliance of Presidential Majority (AMP) of Kabila Bemba's Union for the Nation (UN) and others like the Convention of Congolese Democrats (CODECO) of Pay Pay, Oscar Kashala's Union for the Reconstruction of the Congo (UREC) and Arthur Z'Ahidi Ngoma's Camp de la Patrie. Many small parties also joined forces to support one candidate or the other.

An analysis of the ethnic factor in the presidential election is not easy. Kabila got $58.05 \%$ of the votes against Bemba's $41.95 \%$. In Kinshasa and in Bandundu, there was a rallying of Kabila and Lumumba supporters, (Kabila-Gizenga) and in Equateur between Kabila and Mobutu supporters (J Kabila-Nzang Mobutu). In the central regions, the alliance between Oscar Kashala and Bemba won in both Kasaï states. With the alliance between AMP-PALU and the Union des Mobutistes (UDMO), Kabila reduced some of his isolation in the west. But he did not succeed in eliminating the unrest in the capital.

7 Interview of Albert Kalonji on Digital Congo TV, October 2006. 
The presidential elections ultimately reflected the registration of voters and the trend of voting in the constitutional referendum, depending on whether the population was under 'occupation' or under government authority. In a study on the issue, de Saint Moulin (2006:20) noticed at an early stage 'a peculiar behaviour of the populations of a number of territories in the two Kasais. It is in the Eastern Kasaï that the lowest levels of registration were recorded, and with the exception of the town of Matadi, all the territories or towns where people voted in the negative during the referendum were in the two Kasais... The following observation was based on the first analysis: the three Kivu and Maniema provinces registered and voted massively, thus manifesting a strong desire to integrate into national life. This observation is also true of other regions which were subjected to occupation by rebel or foreign troops: the entire Eastern Province and the north of Equateur...'The author indicates that it is the same trend that was noticed in Sankuru and northern Katanga. Kabila has in effect been massively voted for in the formerly occupied areas. In the capital on the other hand, the linguistic bond between the Swahili-speaking East and the Lingala-speaking West seems to have been a fundamental determining factor in the choice of voters. The two Kasais once again adopted an unusual attitude.

\section{The expression of identities in the electoral tradition}

In light of the Congolese tradition, one can notice that voting behaviour takes several forms.

First, the modification of ethnic allegiance. The quasi-non-existence of individual votes at the presidential level contrasts with the individual vote both at the presidential and the legislative elections, given that even 'brothers' and 'sisters' come into conflict with candidates during elections. The faithfulness of voters must be carefully considered, in the present as in the past. 'All attempts at defining the ethnic factor as a basis for political choice pose a problem which is complicated by the fact that 
sometimes Congolese modify or even enlarge their ethnic allegiance.8 The Congolese electorate is complex.

Second, the conflict of ethnic 'faithfulness' in voting. Belonging to one ethnic group or tribe does not automatically mean uniformity in the political choice of all the members of the community. The equation is complicated when we add the purchasing of consciences. In 1960, a Muluba from Kasaï could vote for the 'federalist' Kalonji. Other Baluba, however, could vote for Sendwe, faithful to the central government, and yet other voted for Tshombe and secession (Weiss 1994:46). Young (1979:112) observes that 'ethnic identity is something ambiguous and opaque... For example, when the Kongo were pitted against the Bangala in Leopoldville, there was a remarkable solidarity among them. But when it was time to elect members of the executive committee for the Kongo ABAKO movement, there were frictions between the various Kongo subgroups (Ntandu, Ndibu, Manianga, Mayombe, etc)'.

The electoral map of the 2006 presidential elections also revealed the limits of ethnic loyalty and the complexity of geopolitics in making choices by the Congolese electorate. In the case of the two main contenders, Bemba and Kabila, nobody got $100 \%$ of the voters' ballots, even in their home provinces.

Third, the 'indigenisation' of political actions and institutions. Often, the decision to alternate is not well understood. Regionalisation and geopolitics play a great role in the appointment in institutions and in the day-to-day running of the state. In the Congo, the formula is generally well-known: the community $\mathrm{X}$ (or ethnic group) does not recognise itself in a government in which it is not represented. 'In people's minds, there is still a deep misunderstanding of the end-purpose of institutions and political actions, which people are trying to indigenize' (Ndaywel 1996:35). ${ }^{9}$ This has given rise to the Congolese tradition of governments of national unity, which are mainly weak and irresponsible.

8 For more information, see Wallerstein 1960, quoted in Weiss 1994:81.

9 It is also good to read Balandier 1982 and Zartman 2000. 
Vice-president Bemba had called for the signing of a 'commitment', aimed at creating a government of national unity between AMP and the $\mathrm{UN}$ after the first round of the presidential elections. The proposal was rejected by the AMP.

Fourth, electoral clientelism. The practice of 'clientelist' votes or electoral clientelism may be defined as the voting for one's 'brother' or 'sociological voting'. It originates from the opinion that voters can only be politically represented by someone with whom they share the same ethnic origins. That is why most of the candidates run for posts in their villages, divisions or provinces and in areas where their kinsmen form a majority. The tribe represents the main point of identity. Ethnicity should therefore be seen as 'an expression... of interactions in which individuals act like members of ethnic groups. [Or better still as] ... cases of political factors that underlie the emergence and persistence of existing ethnic differentiations' (Poutignat \& Streiff-Fenard 1995, in Vinsonneau 2002:120).

The other aspect of electoral clientelism is linked to the inequalities in the distribution of the country's various development projects. People have developed the idea (as one consultant from the Electoral Institute of South Africa commented) that 'our area can only develop if we have a political leader. So people push their kinsmen into politics. ${ }^{10}$ This basic premise has often been true.

\section{Consistent trends in Congolese electoral practice}

\section{Similarities}

Elections in the DRC show many similarities. They are generally based on community allegiances. Money plays quite an important role. Conflict of interest around national leadership favours the emergence of dominant regionalist, pan-tribal factors. However, it needs to be said that the voters' choices in 1960 and in 2006 were essentially, but not exclusively, based on

10 Interview with Dieudonné Bala, Kinshasa, 31 January 2006. 
identity. The divide between the Swahili-speaking East and the Lingalaspeaking West remains evident during presidential elections. Kinshasa always shows a strong voting pattern against leaders from the Eastern Congo: Lumumba in 1960 and Joseph Kabila in 2006. Little by little in the Congo we are witnessing a kind of electoral tradition where 'culture [can] become indicative of ethnicity when it blends in with a mode of consciousness of people about themselves' (Vinsonneau 2002:120).

In any case, it is difficult to distinguish between the influence of the ethnic factor on political parties, and the role that it played in parties in the past and today. The formation of confederations and political cartels during presidential elections follows both objective and subjective patterns according to a loose demarcation. Amin Samir (1994:21) notes that 'in Sub-Saharan Africa, the breakdown of "national" unity often seems to promote "ethnicity" as a basis of legitimacy of competing powers. But Africa is not the only place where these centrifugal forces operate'. And M'Bokolo Elikya adds: 'In African history as well as in current times, ethnicity is certainly not the residue of an obscure tribal tradition; rather it is the endless materialisation of a historic situation where politics is never absent. The most appropriate definitions of ethnic groups actually refer to given political situations' (in Ruano-Borbalan 1998:324).

\section{Differences between the 1960 and 2006 elections}

The impact of ethnicity on the presidential elections must be interpreted differently in 1960 and 2006. The elections of 1960 were organised as universal voting for legislative candidates and second degree voting (at Senate level) for presidential candidates. In 2006 there was general voting at both these levels.

In 1960, 'within the rural masses, ethnicity has always played a role in political identification, but it was incumbent on the leaders themselves to ensure that this factor was applied in the creation of political parties void of rival factions within the same party' (Weiss 1994:194). But the role of ethnicity should not be blown out of proportion, given that various 
forms of support were given to parties, irrespective of whether they were national, regional or tribal parties.

In 2006, on the other hand, clientelism profoundly undermined the discipline of voting and candidatures. In both situations the Kinshasa electorate has as always been the most undecided and versatile, contrary to the situation in the interior where similar traits between voters and candidates constituted an essential element in the voters' decision making.

There are also some special trends that are unique to each period.

\section{The unique features}

Contrary to 1960, in 2006 for the first time, Kasaï did not ally with the Swahili-speaking areas to 'sanction' Kabila whom the Luba Kasai accused of excluding Tshisekedi from the elections. Only the Songye and the Tetela were exceptions to this attitude. Thus 'ethnicity seems to be a global social reality, which determines the long-term ordering of political equilibriums. The ethnic group is a centre of allegiance in either preliminary or subsequent competition with the nation. The mobilisation of ethnic solidarities constitutes a factor of rift in pluralistic states' (Loka-ne-Kongo 1997:10). Paradoxically, no candidate of Kashala, who is of Kasaï origin, was elected in Eastern or Western Kasaï. Yet Kashala was viewed as representative of Tshisekedi. The PPRD's Marco Banguli was not elected in the legislative elections in his stronghold Teke-Humbu of Kinshasa of which he claimed to be the leader. According to Kaputo Samba (1982), the Congolese experience has shown that the phenomenon of ethnicity is different in urban and rural areas.

In 1960, Lumumba of Eastern Kasaï and Gizenga of Kwilu in Bandundu were able to establish their political empire in Kisangani in the East of Congo. This means that 'the existence of ethnic affinities is not necessarily opposed to tribal unity' (Loka-ne-Kongo 1997:9) and to the higher interest of the nation. During the last parliamentary elections the Katangese communities unanimously voted for Moïse Katumbi, 
a southerner who was known for his generosity and social work and was subsequently elected as Governor of Katanga, to the detriment of the majority northern Luba. Also, compared to 1960, the solidarity of the 'people of the upper parts' was falling apart before the geopolitical and linguistic opposition of Bemba and Kabila. This shows again the relativity of ethnicity.

\section{The impact of ethnicity on democratisation and good governance}

\section{Ethnicity as a factor of under-development}

Democracy is at the foundation of good governance. The two cannot be separated. When talking about good governance, it is political governance that concerns us. In light of the last election, observers agree that the Congolese voted badly. It is obvious that with the political identities it is not always the best person who wins. Ethnicity favours bad choice of leaders. Bad choice of leaders sanctions bad governance. Therefore, ethnicity keeps bad governance in place.

In a democracy under construction this effect of identity raises the problem of the role and status of leaders - the whole question of leadership. The resulting leadership crisis may quickly translate, as is often the case in the Congo, into incompetence, corruption and impunity. As the country is trapped in the jaws of a vicious circle, the elected have obligations to the voters and vice versa. This introduces the risk of chronic underdevelopment. The question is how easily can a country descend to that stage? It seems that 'to answer this question, the rapid evolution of the notion of leadership in the Congo has to be analysed in detail, and then research has to be carried out on how the traditional scale of values has been lost in such a short time' (Nagy 1966:47). Together with mechanisms of reproduction and transfer, the issue of Congolese leadership cannot be elucidated without looking at the colonial political and social ideologies. Although such a study is not the focus 
of this article, such an approach is the essential condition for revisiting the Congolese political culture.

Even though ethnicity generally results in bad governance, it is not necessarily the cause. In fact, it is not easy to establish a cause-effect link between ethnicity as a well-defined socio-cultural system, which is partly sub-conscious, and good governance as a 'scientific' concept. In other words, is ethnicity the cultural determinant of governance as a social action? To paraphrase Eugeen Roosens (1979:9), does ethnicity precede bad governance or does it follow as a result? A look at Congolese politics shows that the relation is dialectic: the two dimensions seem to mutually strengthen (and nourish) each other.

In fact, bad management of state affairs in the Congo is not solely linked to electoral practices, for at all times 'at all the levels of political structure, the power of the state and economic powers intermingle, the one feeding the other and vice versa' (Vanderlinden 1978:93). The causal link between ethnicity and the factors that cause bad governance is very difficult to trace. That may be explained according to the multiple facets of ethnicity by what Vanderlinden (1978:92) calls "'typologies" of various "dealings" that take place in contemporary Zairian (Congolese) administration', as well as by the ambiguity and complexity of the concept of good governance. It may be defined as 'a methodology of public administrative action which is based on several pillars: respect for the law, efficiency and democracy' (Delpérée 2002:201-202), but the definition varies according to the socio-political environment.

Phambu Ngoma-Binda (2000:331-336) defines political governance as the correct management of political governance based on nine principles which are all 'supported by ethnic power': the principle of the ethical imperative, the principle of strong resistance to corruption, the principle of separation of powers, the principle of political justice, the principle of democratic compromise, the principle of decentralised federalism, the principle of hospitality, the principle of vertical delegations of power and the principle of firm punishment. When these minimum requirements 
have been accepted, the redirection of the Congolese nation, in a country where everything has to be redone, should be based on the unflinching use of good governance. The results of participatory consultations on the causes of poverty reveal that for Congolese, good governance implies 'human capacity in areas like health, education, environment, food production, public management, culture, management of human and financial resources as well as social and transport infrastructure' (Ministry of Planning 2005:24).

\section{Ethnicity as a factor of conflict}

A recent report by Human Rights ${ }^{11}$ reveals that the manipulation of the notions of ethnicity and citizenship with the aim of targeting political opponents is a common practice in Africa.

The Congolese experience shows that exclusion and all kinds of discrimination are the main ways in which intolerance is expressed during elections. This leads to frustration that can cause all types of conflict. The concepts of 'no son of the soil,' 'stranger,' 'regionalism,' 'provincialism' and even of 'origin of Congo' are ever-present during election periods. Bamesa Tshungu (1996:68) reminds us that "tribalism", ethnicity, regionalism and/or territorialism are omnipresent realities in the political transition field in Zaire [DRC]. Their transformation into instruments has always exacerbated and continues to worsen inter-tribal, inter-ethnic and interregional antagonisms which give rise to intolerance and violence. ${ }^{12}$ The conceptual debate on these issues is almost impossible to manage for the Congo, with its nine international borders, about 215 languages and 450 tribes and several communities and cultures living in the border regions. Conflict is inevitable when ethnicity is mistaken for political identity.

For the Congo to be reborn, there has to be a shift away from the power of ethnicity over political choice.

11 On Radio France International in September 2007.

12 See also Goyvaerts 2000. 


\section{Conclusion}

Our research originated from a regional study on the impact of politics of identity on democratisation and governance in the region of the SADC (Southern African Development Community). The Congolese case study allows us to formulate the following attempts at a solution.

The ethnic factor fundamentally, but not exclusively, determines political choice in the DRC. But that does not mean that all Congolese politics are based on ethnicity. The linguistic and geopolitical component constituted the main cause of rift between the East and the West in the presidential elections. Although ethnicity appears to be the determining factor, the dispersion of votes is a permanent reality in both legislative and presidential elections. But generally speaking, the political identity of the Congo can have ethnic, linguistic, economic or regionalist aspects. In all cases it is difficult, if not impossible, to distinguish the precise role of ethnic belonging in political identity.

Good governance is the departing point of democracy. As observed in the 1960 and 2006 elections, there is obviously a direct link between ethnicity, democracy and good governance in the DRC. It is not easy to establish the causal link between democracy and good governance. The very subjective nature of voting has a very negative impact on political leadership and beyond that, on the proper management of public matters.

In order to bring together the virtues of political identity, democracy and good governance in the Congo, a certain number of recommendations have to be implemented.

- Systematic education has to take place at grassroots level, so that the masses can internalise the notion of democracy and good governance. In this regard the media and civil society can play important roles. 
- Political stakeholders have to be educated and sensitised on their role, rights and obligations according to the demands of democracy and good governance.

- An obligatory military service for youth after their secondary school cycle has to be adopted to instil a patriotic sentiment.

- The capacity and the authority of the State have to be strengthened to improve the condition of life of the population.

- The DRC has to ratify the Anti-corruption protocol signed between member-states of the SADC.

- A common national language has to be adopted.

\section{Sources}

Balandier, G. 1982. Anthropologie politique. Paris: Presses Universitaires de France.

Barth, F. 1969. Les groupes ethniques et leurs frontiers. Bergen, Oslo: Universitetsforlaget

Congo 1960. Vol 1. Brussels: Centre de Recherche et d'Information en Science Politique (CRISP)

Congo 1965. Brussels: Centre de Recherche et d'Information en Science Politique (CRISP)

Delpérée, F. 2002. Gouvernance et fédéralisme culturel, in Organisation Internationale de la Francophonie (OIF), Diversité et Droits culturels, Round table organised in collaboration with the Arabic Institute of Human Rights and the OIF Tunis, 21-23 September 2002. Edited by the International Francophonie Agency.

de Saint Moulin L. 2006. Analyse par territoire et ville des résultats de l'enrôlement des électeurs et du référendum sur le projet de Constitution. Congo-Afrique, no 403, Feb-Mar.

Echos des Elections 2006. No 13, Sept 2006.

Elikya M.1998. Les ethnies existent-elles? Quoted in Ruano-Borbalan 1998.

Goyvaerts, D. (ed) 2000. Conflict and Ethnicity in Africa. Tokyo: Institute of the Study of Languages and Cultures of Asia and Africa, Tokyo University of Foreign Studies.

Journet N. 2002. Que faire de la culture? in Sciences humaines, La Culture. de l'universel au particulier. Paris: Sciences humaines.

Ministry of Planning 2005. Document de Stratégie pour la Réduction de la Pauvreté. Provisional version. Kinshasa: Ministry of Planning.

Nagy, L. 1966. L'apport tribal dans la création et l'évolution des partis politiques congolais, in Genève-Afrique/Geneva-Africa. Acta Africana V (1). 
Ndaywel I. 1996. Power and democracy: a study of political evolution in Zaire, in NgomaBinda, P., La tolérance politique. Kinshasa: IFEP.

Ngoma-Binda, P. 2000. La participation politique: Ethique civique et politique pour une culture de paix, de démocratie et de bonne gouvernance. Kinshasa: IFEP.

Poutignat, P. \& Streiff-Fenard, J. 1995. Théories de l'ethnicité. Paris: Presses Universitaires de France. Quoted in Vinsonneau 2002.

Roosens, E. 1979. Différences culturelles et identité ethnique: Aspect du développement. Brussels: AGCD.

Ruano-Borbalan J.-C. 1998. La construction de l'identité, in Sciences humaines, Identité. Paris: Sciences humaines.

Samba K. 1982. Phénomène d'ethnicité et conflits ethno-politiques en Afrique noire postcoloniale. Kinshasa: PUZ.

Samir, A. 1994. L'ethnie à l'assaut des nations. Yougoslavie, Ethiopie. Paris: L'Harmattan.

Tshungu, B. 1996. La transition politique au Zaïre: intolérance, violence et occasions manquées, in Ngoma-Binda, P. et al, La tolérance politique. Kinshasa: IFEP.

Vanderlinden, J. 1978. Du Congo au Zaïre, 1960-1980. Essai de bilan. Brussels: CRISP.

Vinsonneau, G. 2002. L'identité culturelle. Paris: Armand Colin.

Wallerstein, I. 1960. Ethnicity and National Integration, Cahier d'Etudes Africaines, vol. I, Jul.

Weiss, H.F. 1994. Radicalisme rural et Lutte pour l'indépendance au Congo-Zaïre. Le Parti Solidaire Africain (1959-1960). Paris: L'Harmattan.

Young, C. 1968, Introduction to Congolese politics. Brussels: CRISP

Young, C. 1979. Introduction à la politique zaïroise, $2^{\text {nd }}$ edition. Kinshasa: Presses Universitaires du Zaïre.

Zartman, I.W. 2000. Traditional cures for modern conflicts. African conflict 'medicine'. SAIS African Studies Library. Colorado: Lynne Rienner. 